\title{
Phytoprotection
}

\section{Variability of quackgrass (Agripyron repens) biotypes in Québec}

\section{F.J. Tardif et G.D. Leroux}

Volume 72, numéro 3, 1991

URI : https://id.erudit.org/iderudit/706011ar

DOI : https://doi.org/10.7202/706011ar

Aller au sommaire du numéro

\section{Éditeur(s)}

Société de protection des plantes du Québec (SPPQ)l

\section{ISSN}

0031-9511 (imprimé)

1710-1603 (numérique)

Découvrir la revue

\section{Citer cet article}

Tardif, F. \& Leroux, G. (1991). Variability of quackgrass (Agripyron repens) biotypes in Québec. Phytoprotection, 72(3), 115-121.

https://doi.org/10.7202/706011ar
Résumé de l'article

Une expérience a été menée au champ en 1985 et 1986 à Sainte-Foy (Québec), Canada, dans le but de caractériser la variabilité de la croissance de 10 biotypes de chiendent (Agropyron repens) originaires du Québec. Les variables de la croissance ainsi que le patron d'allocation de la biomasse ont varié significativement entre les biotypes. Les biotypes les plus productifs ont produit au moins trois fois plus de tiges et d'épis que les biotypes les moins productifs. Le nombre de plants-filles a varié entre 6 et 51 . Les biotypes les plus productifs ont produit plus de 1900 bourgeons rhizomateux alors que les moins productifs en ont produit moins de 500. La biomasse sèche totale a varié entre 73 et $241 \mathrm{~g}$ entre les biotypes le moins et le plus productif. Le pourcentage de la biomasse alloué aux parties aériennes a plus varié selon les années et les biotypes que le pourcentage alloué aux rhizomes. La reproduction végétative est plus variable que la reproduction sexuée chez le chiendent. 


\title{
Variability of quackgrass (Agropyron repens ) biotypes in Québec
}

\author{
François J. Tardif and Gilles D. Leroux \\ Département de phytologie, Faculté des sciences de l'agriculture et de l'alimentation, \\ Université Laval, Québec (Québec), Canada G1K 7P4
}

(Received 1991-05-31; accepted 1991-11-12)

\begin{abstract}
Field experiments were conducted in 1985 and 1986 at Sainte-Foy, Québec, Canada, to characterize the growth variability of 10 quackgrass (Agropyron repens) biotypes collected in Québec. The growth variables and the pattern of biomass allocation differed significantly among biotypes. Three-fold difference existed among biotypes for the number of tillers and spikes. The number of daughter-shoots varied from 6 to 51 . More than 1900 rhizome buds were formed by the most productive biotypes and fewer than 500 by the least productive ones. Biomass varied from 73 to $241 \mathrm{~g}$ dry weight between the least and the most productive biotype. The percentage of total biomass allocated to the mother-shoot and the daughter-shoots varied more between years and among biotypes than the percentage allocated to the rhizomes. Reproduction in quackgrass is predominantly vegetative and sexual reproduction is more variable among biotypes and years.
\end{abstract}

Tardif, F.J., and G.D. Leroux. 1991. Variability of quackgrass (Agropyron repens) biotypes in Québec. PHYTOPROTECTION 72: 115-121.

Une expérience a été menée au champ en 1985 et 1986 à Sainte-Foy (Québec), Canada, dans le but de caractériser la variabilité de la croissance de 10 biotypes de chiendent (Agropyron repens) originaires du Québec. Les variables de la croissance ainsi que le patron d'allocation de la biomasse ont varié significativement entre les biotypes. Les biotypes les plus productifs ont produit au moins trois fois plus de tiges et d'épis que les biotypes les moins productifs. Le nombre de plants-filles a varié entre 6 et 51. Les biotypes les plus productifs ont produit plus de 1900 bourgeons rhizomateux alors que les moins productifs en ont produit moins de 500 . La biomasse sèche totale a varié entre 73 et $241 \mathrm{~g}$ entre les biotypes le moins et le plus productifs. Le pourcentage de la biomasse alloué aux parties aériennes a plus varié selon les années et les biotypes que le pourcentage alloué aux rhizomes. La reproduction végétative est plus variable que la reproduction sexuée chez le chiendent.

\section{Introduction}

Quackgrass (Agropyron repens [L.] Beauv.; syn.: Elytrigia repens [L.] Desv.) is a perennial rhizomatous species found in all the major agricultural areas of the north and south temperate zones (Holm et al. 1977; Werner and Rioux 1977). In sexual reproduction it is allogamous and autosterile (Palmer and Sagar 1963). Limited sexual reproduction allows recombination of characters and thus provides the opportunity to respond to environmental changes and to invade new sites. Quackgrass reproduces mainly by rhizomes enabling those genotypes that are best adapted to local conditions to rapidly colonize a particular site. Since it tends to produce clones, a colony of quackgrass may include one or a few different genotypes even though it is composed of a large number of individual plants. All the

$\overline{0031-9511 / 91} \$ 1.00+.10$ individuals with the same genotype are then defined as a biotype (Stebbins 1950).

Research conducted in Europe and the United States showed that a large amount of variation exists among several biotypes or clones of quackgrass (Neuteboom 1975; Westraand Wyse 1981; Williams 1973). Characters that confer to quackgrass the ability to invade fields and to compete with crops were found to differ among biotypes.

The majority of weeds that invade crops are known to be very variable in growth and development. In Québec, the range of biotype variability in relation to the growth characteristics of quackgrass is not known. The objective of this study was to determine the extent of the variability found in 10 quackgrass biotypes from different localities of the province by measuring different growth variables bearing agronomic significance. Furthermore, resource allocation between mother-shoots, daughtershoots and rhizomes was determined in order to acquire a better knowledge of the growth strategy of this plant under the conditions of Eastern Canada. 


\section{Material and methods}

In 1984, more than 100 clones were collected from quackgrass plants harvested in many rural localities of Québec. A rhizome section was taken from each clone and planted in a $1-\mathrm{L}$ pot filled with standard potting mixture composed of peat moss, decomposed organic soil, sand, vermiculite and perlite $(2: 2: 2: 1: 1 ; \mathrm{v} / \mathrm{v} / \mathrm{v} /$ $\mathrm{v} / \mathrm{v})$. These plants were grown in a greenhouse where the natural light was complemented by high pressure sodium lamp for a maximum photon flux of $450 \mu \mathrm{mol} /\left(\mathrm{m}^{2} \bullet \mathrm{s}\right)$. The pots were fertilized once a week with a solution of 1000 ppm of nitrogen, phosphorus and potassium. Temperature varied between $20^{\circ} \mathrm{C}$ and $25^{\circ} \mathrm{C}$. Under these conditions, the biotypes produced many rhizomes after three months.

Ten biotypes were chosen from the collection according to the following phenotypic characters: awn length, hairiness of both rachis and leaf blade, leaf blade width and color (Table 1). The expression of these phenotypic characters remained constant for each biotype throughout the experiment. These characters were measured on 10 plants of each biotype grown in the greenhouse. Biotype 2, which originated from Sainte-Foy near the experimental site, was used as a local control. It was assumed that this biotype was well adapted to the climatic and environmental conditions that would prevail during the course of the experiment and that this would be a reference with which to compare the other biotypes. The chromosome number of the 10 biotypes was counted from root tips sampled on greenhousegrown plants.

The experiment was conducted at SainteFoy on the Laval University campus in 1985 and was repeated in 1986 at an adjacent location. The soil at the experimental site is a SaintNicolas gravelly loam $(\mathrm{pH} 6.4 ; 2.5 \%$ organic matter; $430 \mathrm{~kg} / \mathrm{ha} \mathrm{P} ; 575 \mathrm{~kg} / \mathrm{ha} \mathrm{K}$ ). Mineral fertilizer was broadcast in spring at rates of 100 $\mathrm{kg} / \mathrm{ha} \mathrm{P}_{2} 0_{5}, 100 \mathrm{~kg} / \mathrm{ha} \mathrm{K} \mathrm{K}_{2}$, and $75 \mathrm{~kg} / \mathrm{ha} \mathrm{N}$. Annual weeds were controlled with $0.3 \mathrm{~kg}$ a.i./ ha of dicamba (3,6-dichloro-2-methoxy benzoic acid) and $2.0 \mathrm{~kg}$ a.i./ha of metolachlor [2chloro- $N$-(2-ethyl-6-methylphenyl)- $N$-(2methoxy-1-methylethyl) acetamide] applied prior to transplanting. Weeds escaping the treatment were handweeded. To minimize the stress after transplanting in the field, single node rhizome sections of the biotypes were planted in $5 \mathrm{~cm} \times 5 \mathrm{~cm}$ peat pots. They were grown in the greenhouse until they reached the 3- to 4- leaf stage and planted on 6 May 1985 and 20 May 1986. The experiment had four replications in a split-plot design with two harvest dates as main plot and 10 biotypes as subplot, each with two single plants as subsamples. Each plant was spaced in a grid $2 \mathrm{~m}$ apart in order to avoid overlapping of the rhizomes between plots.

Individual plants were harvested 75 and 105 days after transplanting in the field. For each plant, a distinction was made between the original mother-shoot, the rhizomes, and the daughter-shoots that were produced from the rhizomes. The daughter-shoots were counted, then the mother and daughter-shoots were cut at ground level and placed separately in paper bags. The rhizomes were dug out to $15 \mathrm{~cm}$ depth and placed in paper bags. The total number of tillers and flowering spikes (referred to as spikes) of individual plants (sum of mother-and daughter-shoots) was counted. The rhizomes were washed free of debris and the number of buds counted. All samples were dried at $70^{\circ} \mathrm{C}$ until constant weight for dry biomass determination. Total biomass of individual plants was computed as the sum of the biomass of the mothershoot, daughter-shoots and rhizomes. The percentages of dry matter allocation to these plant parts were then calculated. The relative growth rates (RGR) of the biotypes were calculated for the whole plants (RGRt), the shoots (RGRs) and the rhizomes (RGRr). The basic formula was:

$$
\mathrm{RGR}=1 / \mathrm{W}_{1}\left\{\left(\left[\mathrm{~W}_{2}-\mathrm{W}_{1}\right] 1000\right) 1 / \mathrm{t}\right\}
$$

where $\mathrm{W}_{1}=$ biomass at harvest $1 ; \mathrm{W}_{2}=$ biomass at harvest 2; and $\mathrm{t}=$ days between harvests (Radosevich and Holt 1984).

The data of each year were combined and submitted to standard analysis of variance (SAS Institute Inc. 1985). The homogeneity of the variance was ascertained by using the BurrFoster test (Anderson and McLean 1974). Non homogeneous variables were transformed using the square-root transformation. Pearson's coefficients of correlation between all variable combinations were determined using single observations of 1985 and 1986. 


\section{Results and discussion}

Comparison of the growth of the biotypes. All the biotypes of this study, except biotype 2 from Laval University, originated from $150 \mathrm{~km}$ to $250 \mathrm{~km}$ west of Sainte-Foy (Table 1). The chromosome number of the 10 biotypes was $2 n=42$ and this is the number usually reported for this species (Werner and Rioux 1977). Because significant interactions $(P \leq 0.05)$ existed between biotypes and years for all variables, the yearly data are presented. Significant differences existed among biotypes for all variables studied. Biotypes 5 and 9 produced the highest number of daughtershoots in both 1985 and 1986(Table 2). Biotypes 9 and 10 produced the most tillers in 1985 and 1986, respectively. Biotype 9 produced the highest number of spikes in both years. Biotype 8 in 1985 and biotype 5 in 1986 produced the least number. Biotypes 5 and 9 produced the greatest number of rhizome buds in each year. The highest total biomass was produced by biotypes 5 and 9 in 1985 and 1986, respectively. Biotype 9 produced the highest daughter-shoot biomass and the highest rhizome biomass in both years.

For most variables, the productivity of local biotype 2 was inferior to the average of the 10 biotypes. Biotype 2 was always significantly different than the most productive biotypes, except for the number of spikes in 1985 and the mother-shoot biomass in both 1985 and 1986.
The number of spikes and the mother-shoot and daughter-shoot biomass differed significantly between years $(P \leq 0.01)$. The number of spikes and the mother-shoot biomass was on the average higher in 1985 than 1986 (Table 2). Conversely, the mean daughter-shoot biomass was higher in 1986 than 1985. There was no significant difference between years for the other variables. A significant interaction between years $(P \leq 0.05)$ and biotypes was measured for almost all variables. Most of this interaction resulted from the different behavior of biotype 10 which had much greater growth in 1986 (Table 2).

Dynamics of growth. The relative growth rate (RGRt) on a whole plant basis significantly $(P \leq 0.05)$ differed among biotypes (Table 3$)$. The relative growth rate of the shoots (RGRs) did not differ among $(P \leq 0.05)$ biotypes in 1985 , but differences occurred in 1986. The values of the relative growth rate of rhizomes (RGRr) differed significantly among biotypes in both 1985 and 1986. Differences between the most and the least productive biotypes were more pronounced in 1986 than in 1985.

Allocation of biomass to plant parts. The relative importance of the aboveground and underground parts of each biotype is determined by the percentage of the total biomass allocated to the mother-shoot, daughter-shoot, and to the rhizomes. Significant differences $(P \leq 0.05)$ in biomass allocation to the three plant parts were

Table 1. Phenotypic characters, original habitat and locality of the 10 quackgrass biotypes

\begin{tabular}{|c|c|c|c|c|c|c|c|c|}
\hline \multirow[b]{2}{*}{ Biotype } & \multirow{2}{*}{$\begin{array}{l}\text { Laval } \\
\text { University } \\
\text { collection } \\
\text { number }\end{array}$} & \multirow{2}{*}{$\begin{array}{l}\text { Awn } \\
\text { length } \\
(\mathrm{mm})^{\S}\end{array}$} & \multicolumn{2}{|c|}{ Hairiness } & \multirow{2}{*}{$\begin{array}{l}\text { Leaf } \\
\text { blade } \\
\text { width } \\
(\mathrm{mm})^{\S}\end{array}$} & \multirow[b]{2}{*}{ Color } & \multirow[b]{2}{*}{ Original habitat } & \multirow[b]{2}{*}{ Locality and county } \\
\hline & & & rachis & leaf & & & & \\
\hline 1 & NGL07 & 4.0 & No & Yes & 5.3 & Blue & Vegetable field & New-Glasgow, (Montcalm) \\
\hline 2 & ULA02 & 0 & No & No & 5.7 & Green & Waste land & Laval University, (Sainte-Foy) \\
\hline 3 & RAW01 & 1.5 & No & Yes & 6.0 & Blue & Corn field & Rawdon, (Montcalm) \\
\hline 4 & SALO1 & 1.0 & Yes & Yes & 7.0 & Green & Vegetable field & Saint-Alexis, (Montcalm) \\
\hline 5 & MTL05 & 0 & Yes & Yes & 7.0 & Blue & Waste land & Montréal, (Lafontaine) \\
\hline 6 & SBR01 & 0 & Yes & Yes & 5.0 & Green & Cereal field & Saint-Bruno, (Chambly) \\
\hline 7 & MON05 & 0 & Yes & No & 6.3 & Green & Vegetable field & Saint-Jacques, (Montcalm) \\
\hline 8 & SAL03 & 0 & Yes & Yes & 7.3 & Green & Corn field & Saint-Alexis, (Montcalm) \\
\hline 9 & $\mathrm{SDO} 02$ & 0 & No & Yes & 5.0 & Blue & Corn field & Sainte-Dorothée, (Laval) \\
\hline 10 & SAL02 & 4.0 & No & Yes & 4.0 & Green & Vegetable field & Saint-Alexis, (Montcalm) \\
\hline
\end{tabular}

$\S$ Average of 10 samples of each biotype from greenhouse-grown plants. 
Table 2. Growth of individual plants of 10 quackgrass biotypes in 1985 and 1986 at Sainte-Foy, Québec $\$$

\begin{tabular}{|c|c|c|c|c|c|c|c|c|c|c|c|c|}
\hline \multicolumn{13}{|c|}{ Biotype } \\
\hline Year & 1 & 2 & 3 & 4 & 5 & 6 & 7 & 8 & 9 & 10 & mean & S.e.d. ${ }^{\dagger}$ \\
\hline \multicolumn{13}{|c|}{ Daughter-shoots (number / plant) } \\
\hline 1985 & 10 & 15 & 7 & 16 & 38 & 18 & 12 & 9 & 51 & 24 & 20 & 7.4 \\
\hline 1986 & 17 & 20 & 6 & 14 & 49 & 12 & 11 & 15 & 41 & 28 & 15 & 6.0 \\
\hline \multicolumn{13}{|c|}{ Tillers (number / plant) } \\
\hline 1985 & 121 & 139 & 154 & 180 & 202 & 14 & 116 & 85 & 308 & 175 & 164 & 41.6 \\
\hline 1986 & 118 & 192 & 96 & 143 & 266 & 146 & 103 & 111 & 258 & 351 & 178 & 37.6 \\
\hline \multicolumn{13}{|c|}{ Spikes (number / plant) } \\
\hline 1985 & 26 & 38 & 49 & 56 & 30 & 49 & 37 & 21 & 58 & 28 & 40 & 9.6 \\
\hline 1986 & 17 & 18 & 26 & 35 & 15 & 42 & 23 & 23 & 61 & 32 & 29 & 8.4 \\
\hline \multicolumn{13}{|c|}{ Rhizome buds (number / plant) } \\
\hline 1985 & 855 & 948 & 1239 & 862 & 1783 & 869 & 846 & 643 & 2051 & 642 & 1096 & 244.0 \\
\hline 1986 & 926 & 1060 & 969 & 1092 & 1995 & 876 & 452 & 850 & 1925 & 1358 & 1150 & 249.0 \\
\hline \multicolumn{13}{|c|}{ Total biomass (g dry weight / plant) } \\
\hline 1985 & 83 & 137 & 124 & 151 & 212 & 179 & 117 & 118 & 203 & 83 & 143 & 33.0 \\
\hline 1986 & 73 & 116 & 86 & 109 & 220 & 183 & 77 & 157 & 241 & 190 & 145 & 31.9 \\
\hline \multicolumn{13}{|c|}{ Mother-shoot biomass (g dry weight / plant) } \\
\hline 1985 & 35 & 52 & 58 & 59 & 56 & 60 & 37 & 34 & 35 & 35 & 47 & 10.4 \\
\hline 1986 & 21 & 18 & 18 & 25 & 19 & 40 & 29 & 36 & 17 & 31 & 25 & 7.7 \\
\hline \multicolumn{13}{|c|}{ Daughter-shoot biomass ( $g$ dry weight / plant) } \\
\hline 1985 & 6 & 12 & 6 & 22 & 41 & 22 & 17 & 20 & 50 & 3 & 20 & 12.8 \\
\hline 1986 & 17 & 33 & 19 & 29 & 78 & 44 & 13 & 37 & 87 & 52 & 41 & 12.1 \\
\hline \multicolumn{13}{|c|}{ Rhizome biomass (g dry weight / plant) } \\
\hline 1985 & 42 & 73 & 60 & 70 & 115 & 97 & 63 & 64 & 118 & 45 & 76 & 16.9 \\
\hline 1986 & 35 & 65 & 49 & 55 & 123 & 99 & 35 & 84 & 137 & 107 & 79 & 16.0 \\
\hline
\end{tabular}

$\S$ Each value is the mean of 8 observations ( 4 replications and 2 subsamples).

$\uparrow$ Standard error of the difference.

Table 3. Dynamics of the relative growth rate for whole plants (RGRt), shoots (RGRs) and rhizomes (RGRr) of 10) quackgrass biotypes in 1985 and 1986 at Sainte-Foy, Québec

\begin{tabular}{|c|c|c|c|c|c|c|c|c|c|c|c|}
\hline \multicolumn{12}{|c|}{ Biotype } \\
\hline Year & 1 & 2 & 3 & 4 & 5 & 6 & 7 & 8 & 9 & 10 & S.e.d. ${ }^{\dagger}$ \\
\hline \multicolumn{12}{|c|}{$R G R t(m g / l g$. day $])$} \\
\hline 1985 & 54 & 98 & 58 & 49 & 105 & 108 & 86 & 117 & 174 & 89 & 57 \\
\hline 1986 & 36 & 137 & 65 & 153 & 209 & 82 & 76 & 209 & 86 & 130 & 48 \\
\hline \multicolumn{12}{|c|}{ RGRs (mg/lg . day]) } \\
\hline 1985 & 44 & 105 & 46 & 31 & 68 & 75 & 54 & 123 & 139 & 65 & 72 \\
\hline 1986 & 75 & 132 & 59 & 132 & 183 & 81 & 58 & 245 & 74 & 103 & 45 \\
\hline \multicolumn{12}{|c|}{$\operatorname{RGRr}(\mathrm{mg} /[\mathrm{g} \cdot \mathrm{day}])$} \\
\hline 1985 & 77 & 105 & 71 & 91 & 173 & 166 & 158 & 116 & 210 & 115 & 56 \\
\hline 1986 & 45 & 147 & 70 & 151 & 218 & 101 & 198 & 188 & 88 & 168 & 59 \\
\hline
\end{tabular}

$\$$ Standard error of the difference. 
found among biotypes in 1985 and 1986. For the majority of the biotypes, the allocation to the rhizomes represented over $50 \%$ of the total biomass (Fig. 1). In 1985, the allocation to the daughter-shoots was less important than in 1986 for nearly all biotypes. Conversely, the allocation to the mother-shoots was higher in 1985.

Correlation between variables. Total biomass was highly correlated $(r \geq 0.80)$ with rhizome and daughter-shoot biomass, but to a lesser extent with that of the mother-shoot $(r \leq 0.50)$. The biomass of the mother-shoot was not significantly correlated with any other variables except the number of spikes $(r \geq 0.41)$. Both the daughter-shoot biomass and the rhizome biomass were highly correlated $(r \geq 0.58)$ with all other variables except the mother-shoot biomass.

Our results indicate that the growth of the 10 quackgrass biotypes varied widely underQuébec
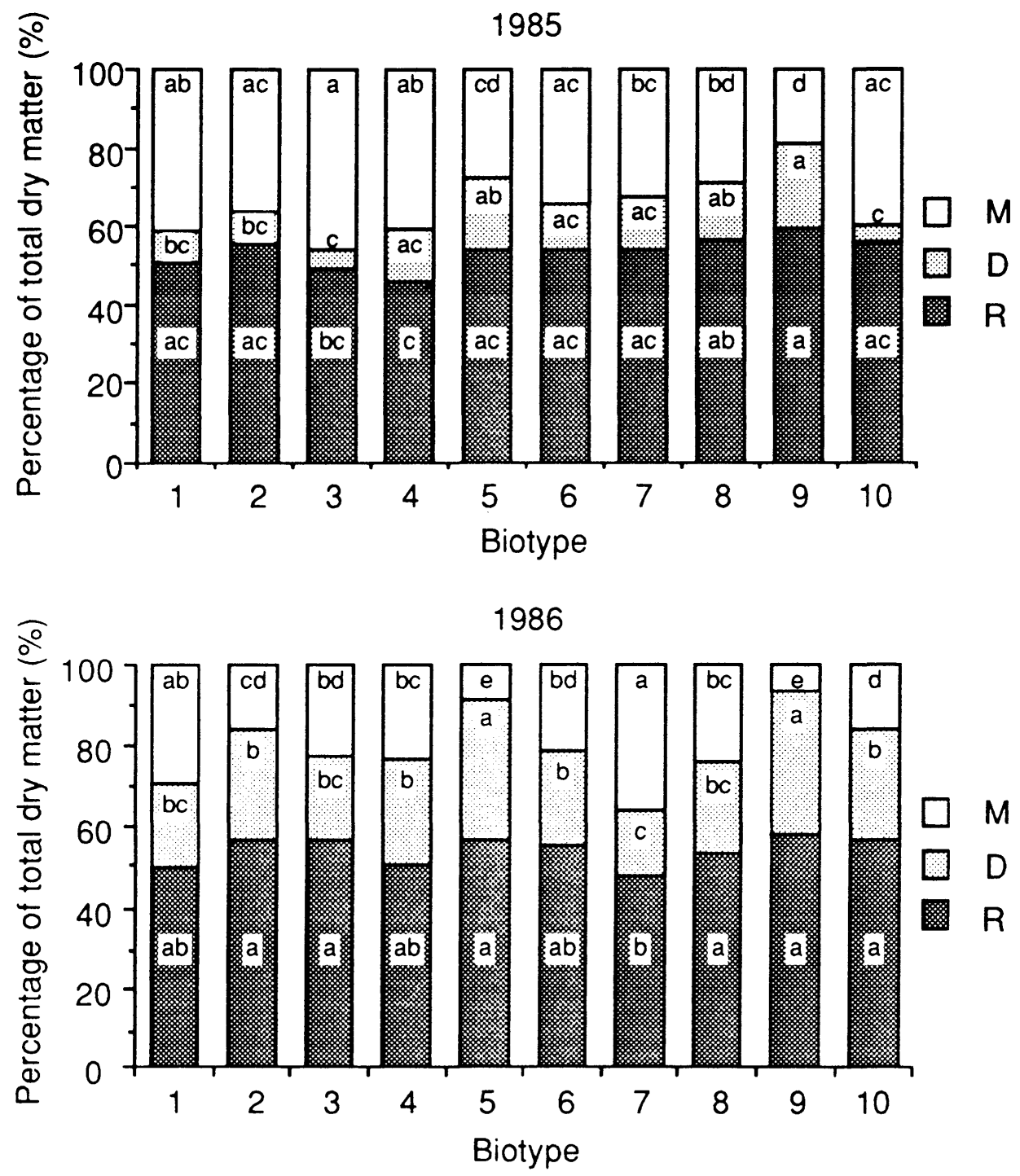

Figure 1. Percentage of the total dry biomass allocated to the mother-shoot (M), daughter-shoots (D) and rhizomes $(R)$ of the 10 biotypes in 1985 and 1986. For each variable (M, D, or R) in each year, the bars with a same letter are not significantly different according to the standard error of the difference. 
conditions of 1985 and 1986. The 10 selected biotypes displayed similar ranking in each year. Biotype 2 which was collected near the experimental site was not among the most productive biotypes. It seems possible that it is a naturally low productive biotype and that some biotypes from other localities were not adversely affected by the growing conditions that prevailed in Sainte-Foy.

The variable production of daughter-shoots, tillers, spikes, and rhizome buds may affect the competitiveness, spreading ability or reproductive potential of the biotypes. For example, a biotype that produces twice as many rhizome buds than another biotype is more likely to be difficult to control because there are many more regenerative organs to kill. The number of daughter-shoots produced by quackgrass clones was positively correlated with their ability to fill up open patches in ryegrass fields (Neuteboom 1981).

The relative growth rates, either calculated on a whole plant basis or for the shoots and rhizomes, represent an efficiency index of the biotypes. The RGR for both the shoots and the rhizome were generally correlated with the whole plant RGR. However, there is no general linkage between RGR and the absolute amount of biomass accumulated. Those biotypes that produced the most biomass were not necessarily those with the highest RGR. For some biotypes the growth rates differed between years. This suggests that differences in climatic conditions that prevailed between years had more effect on certain biotypes than on others. Because the relative growth rates and the absolute production of biomass varied, it is expected that the behaviour of a quackgrass population under given conditions could differ depending on the biotypes.

While the growth of the mother-shoots was superior to that of daughter-shoots in 1985, the opposite trend occurred in 1986. But in each year, the total of the mean mother- and daughter-shoot biomass were nearly the same, ca. 66$67 \mathrm{~g}$ (Table 2). This different behavior in biomass partitioning between years did not influence the mean total biomass nor the number of tillers. As a result, there was no difference between years for the number of tillers and the total biomass. As compared to 1985, fewer spikes were produced in 1986 and this coincides with the superior growth of the daughter- shoots and the reciprocally weaker growth of the mother-shoots during that year. Daughtershoots were less mature than mother-shoots at harvest (because mother-shoots are planted) and they tended to produce less spikes. In our study, the production of spikes was highly influenced by climatic conditions. Thirty percent more spikes were produced under the dry 1985 conditions than during the more humid 1986 growing season. Westra and Wyse (1981) reported similar results with 10 quackgrass biotypes growing in Minnesota at two different locations with different climatic conditions. Thus it seems that in quackgrass, the sexual reproductive effort (indicated by spike production) is less predominant and stable than the vegetative reproduction (rhizome production).

The correlation coefficients between the different growth variables of the biotypes suggest that the biomass of the rhizomes is the best indicator of the overall growth potential of the plant. Growth of the mother-shoot is independent of that of the rhizomes and daughter-shoots. Moreover, the narrow positive correlation between the biomass of the daughter-shoots and that of the rhizomes is obvious: rhizomes must be produced before daughter-shoots can emerge. Therefore, biotypes producing abundant rhizome biomass, can produce a high number of daughter-shoots.

In view of the variability existing among biotypes, the efficacy of different control measures could vary depending on the biotype. When assessing any method of control, it is of prime importance to take into account the variability of quackgrass by using the most frequent local biotypes. Over half the total biomass was allocated to rhizomes and this was the most stable trait throughout the experiment. On the other hand, the growth of the aboveground parts and especially the spike production was much more variable. This indicates that quackgrass invests preferentially into rhizome growth than into sexual reproductive effort.

The authors thank Mr. Jean-Claude Lainé and Ms. Claire Boulanger for their valuable technical help during the course of this project. This research was conducted with the financial help of the Natural Sciences and Engineering Research Council of Canada and the Conseil des recherches en pêche et agro-alimentaire du Québec.

Anderson, U. L., and R.A. McLean. 1974. Designs of experiments. Marcel Dekker, ed., New York. 418 pp. 
Holm, L. G., D.L. Plucknett, J.V. Pancho, and J.P. Herberger. 1977. The world's worst weeds. University Press of Hawaii, Honolulu, Hawaii. 609 pp.

Neuteboom, J. H. 1975. Variability of Elytrigia repens (L.) Desv. (syn. Agropyron repens [L.] Beauv.) on Dutch agricultural soils. Meded. Landbouwhogesch. Wageningen 7: 1-29.

Neuteboom, J. H. 1981. Effect of different mowing regimes on the growth and development of four clones of couch (Elytrigia repens [L.] Desv.; syn. Agropyron repens [L.] Beauv.) in monocultures and in mixtures with perennial ryegrass (Lolium perenne $\mathrm{L}$.). Meded. Landbouwhogesch. Wageningen 15: 1-26.

Palmer, J. H., and G.R.Sagar. 1963. Agropyron repens (L.) Beauv. J. Ecol. 51: 783-794.
Radosevich, S. R., and J.S. Holt. 1984. Weed ecology: implications for vegetation management. Wiley and Sons, New York. 265 pp.

SAS Institute Inc. 1985. SAS ${ }^{\circledR}$ User's Guide: Statistics, Version 5 Edition. Cary, NC. 956 pp.

Stebbins, G. L. 1950. Variation and evolution in plants. Columbia University Press, New York. 643 pp.

Werner, P. A., and R. Rioux. 1977. The biology of Canadian weeds. 23. Agropyron repens (L.) Beauv. Can. J. Plant Sci. 57: 905-919.

Westra, P., and D.L. Wyse. 1981. Growth and development of quackgrass (Agropyron repens ) biotypes. Weed Sci. 29: 44-52.

Williams, E. D. 1973. Variation in growth of seedlings and clones of Agropyron repens (L.) Beauv. Weed Res. 13: 24-41. 